\title{
The Petrology of the Kaapvaal Craton Mantle Lithosphere - a synopsis based on Xenolith Field Counts
}

\author{
Ben Harte ${ }^{1}$, J. Barry Dawson ${ }^{1}$, John J. Gurney ${ }^{2}$, Tim Ivanic ${ }^{3}$. Steve Richardson ${ }^{2}$ \\ 1) School of GeoSciences, University of Edinburgh, Edinburgh, Scotland, Great Britain, ben.harte@ed.ac.uk \\ 2) Geological Sciences, University of Cape Town, Rondebosch, South Africa, john.gurney@minserv.co.za \\ 2) Geological Sciences, University of Cape Town, Rondebosch, South Africa, steve.richardson@uct.ac.za \\ 3) Department of Mines and Petroleum, Perth, Western Australia, Australia, tim.ivanic@dmp.wa.gov.au.
}

\section{Introduction}

The dumps of rock material from the mining operations of kimberlite pipes in the Northern Cape and Free State (South Africa) towards the end of the $19^{\text {th }}$ century, have provided an invaluable source of mantle xenoliths/nodules for over 100 years. Sampling of these nodules, particularly in the second half of the $20^{\text {th }}$ century, led to selective collecting of the less common rocks (e.g. clinopyroxene-rich samples, deformed peridotites), with the result that the dump exposures became unrepresentative of the original rock proportions. Reworking of the dumps for diamonds around the beginning of the $21^{\text {st }}$ century, led to the exposure of new material. To take advantage of these 'fresh' exposures we spent several days on the ground (Figure 1) in November 2004 counting xenolith proportions under the guidance of Jock Robey of De Beers Consolidated mines. At the same time a xenolith count was made at the Letseng La Terae mine in Lesotho. The data collected in 2004 are presented in conjunction with a field count (1979) on the Jagersfontein 'floors', and observations on the natural exposures at Matsoku (Lesotho).

\section{Old South African Mine dumps}

Xenolith counts were made on areas of reworked dump material at Boshof Road (mainly from the Bultfontein mine), Kenilworth (De Beers mine) and Roberts Victor mine.

The data on xenolith proportions for these three localities are summarised in Figure 2 ( the data shown is only for the reworked areas). In addition, data are given on xenolith proportions counted on the old Jagersfontein 'floors' in 1979 (by John Gurney, Barry Dawson, Craig Smith and Ben Harte). As expected the most abundant mantle xenoliths at all localities were olivine- and orthopyroxenerich harzburgites and lherzolites of reasonably coarse grain size, and commonly containing limited amounts (typically estimated at $<10$ modal \%) of garnet and clinopyroxene. Essentially each type of xenolith (harzburgite, lherzolite, and their garnet-bearing varieties) was named according to the presence or absence of clinopyroxene and garnet.

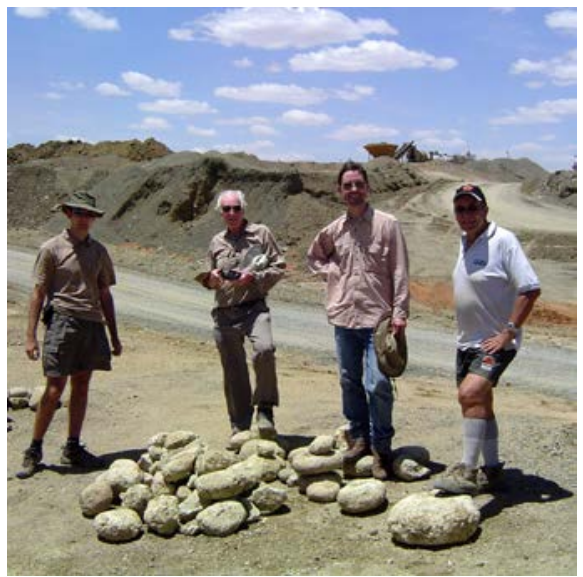

Figure 1: Tim Ivanic, Barry Dawson, Steve Richardson and John Gurney with xenoliths collected on the reworked Kenilworth Flats.

However, rare and small grains of possible clinopyroxene were ignored in many harzburgites. At each locality the common harzburgites, lherzolites, garnet harzburgites and garnet lherzolites appeared to form a continuum with only small variations in mode distinguishing them. Nonetheless, there were some variations from locality to locality in grain size and the overall abundance of clinopyroxene and garnet. Overall the grain sizes were commonly in the range of 1.5 to $7 \mathrm{~mm}$; with orthopyroxene tending to be the largest and clinopyroxene the smallest crystals.

The common coarse peridotites described above clearly appear to dominate the lithospheric mantle on the basis of many studies of their temperatures and pressures of formation. They also show modal and bulk compositions indicating depletion in basaltic major-minor elements. Such depletion is evidently 
partly offset by the occurrence of injection phenomena in the form of intrusive sheets or veins, or in some cases more pervasive metasomatic infiltration. Such injections are seen in the second major group of peridotitic xenoliths found at Bultfontein and De Beers mines; namely the modal metasomatic and MARID rock group (Figure 2). In the field, the typical minerals of these injection and metasomatic phenomena are: phlogopite, amphiboles, opaque minerals, and clinopyroxene. Elongate crystals, probably of richteritic amphibole, were common in these rocks and presumed to indicate MARID suite xenoliths (Dawson 1987, Erlank et al. 1987). Glimmerites, rich in mica, were included in this grouping.

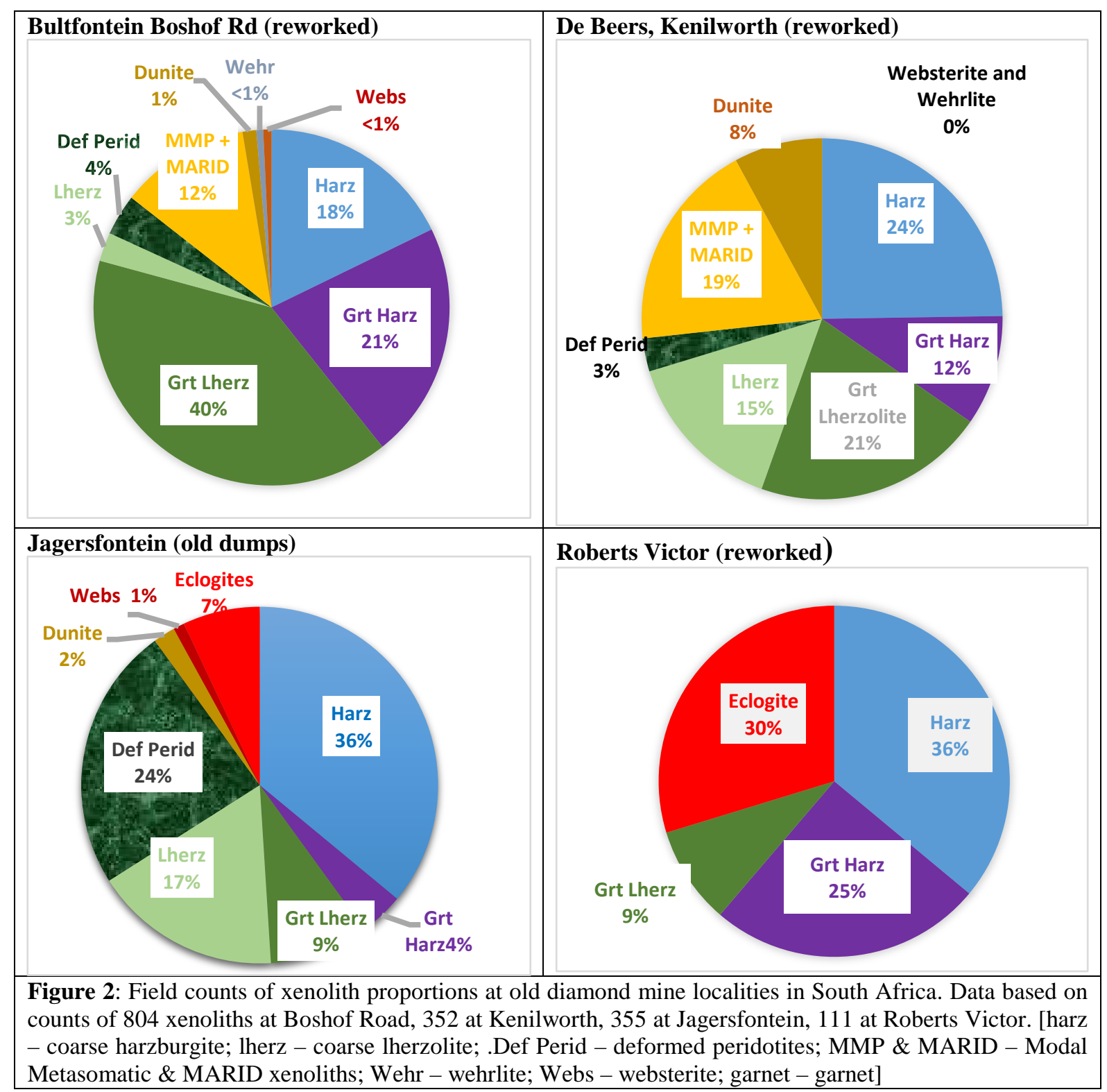

Veined and metasomatised mantle material was not generally recognised at Jagersfontein, where metasomatism involves the presence of an edenitic amphibole (e.g. Johnston 1973; Winterburn et al. 1990). This amphibole is difficult to distinguish from pyroxene in the field and amphibole-bearing xenoliths were not recorded separately from lherzolites. At Roberts Victor the peridotite xenoliths seen in November 2004 were generally very altered (phlogopitised) and mantle metasomatic phenomena were not distinguished, though they have been recorded in the literature.

Deformed peridotites, typically with a foliated character and porphyroclasts of garnet and pyroxene set in a fine-grained matrix of olivine, were a small but regular occurrence at the Bultfontein, De Beers and Jagersfontein localities (Figure 2). Jagersfontein and Roberts Victor were also distinguished by the 
presence of eclogites (including kyanite eclogites). The eclogite to peridotite proportions we found at Roberts Victor were well below the $>95 \%$ eclogite abundance given by Hatton and Gurney (1987).

\section{Lesotho Localities}

Unlike the South African localities, the material examined at Letseng La Terae, in November 2004, was discard and concentrate from the crushing plant (rather than the smooth nodules of the Kimberley dumps, seen in Figure 1). The samples being relatively small were not so readily identified. However, the results of the count were similar to those of Bultfontein and De Beers, except that harzburgites formed a much higher proportion of the coarse peridotites. Dunites and/or deformed and recrystallised megacrysts were also relatively conspicuous.

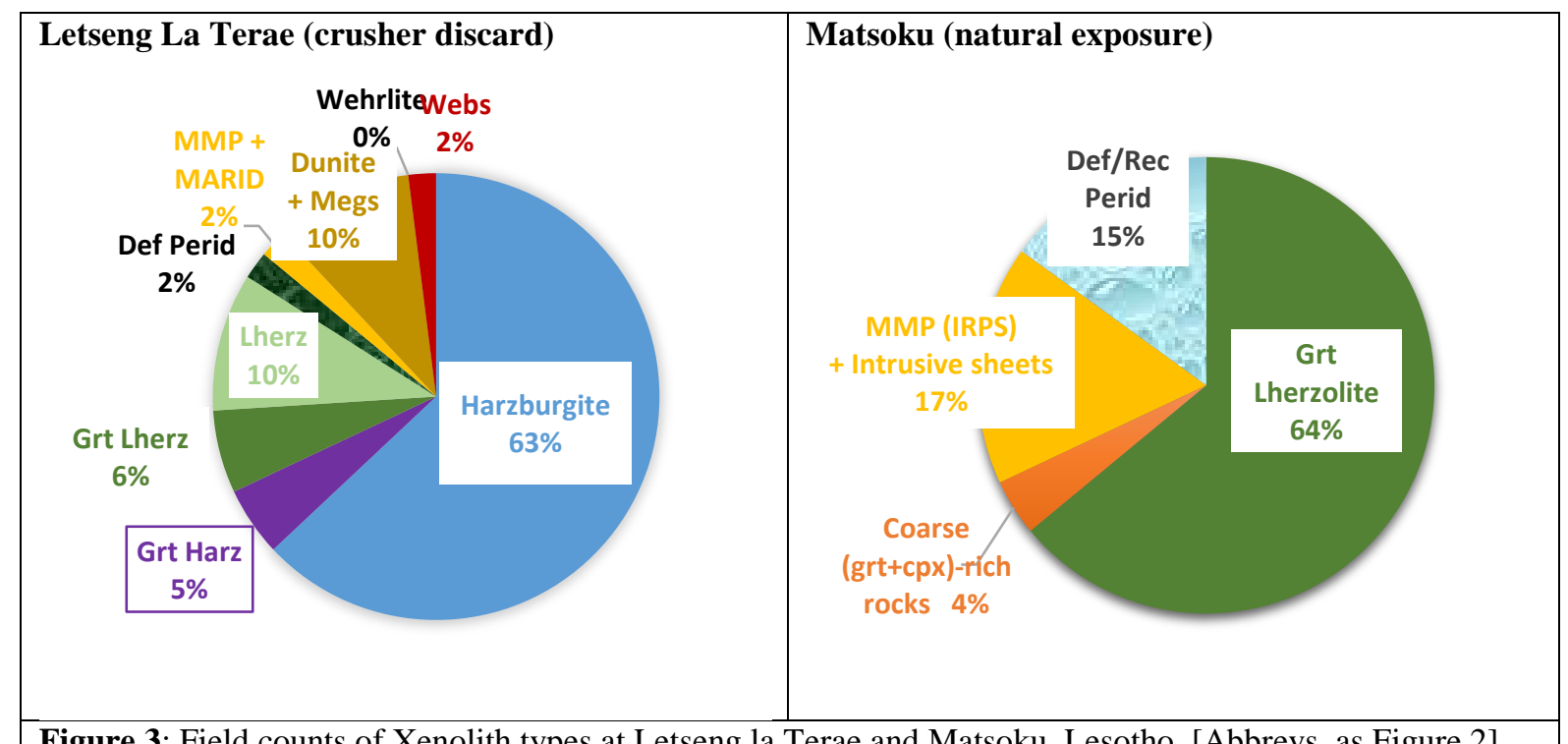

The Matsoku field count given in Figure 3 is based upon data collected in 1968 and 1973, but is given here to highlight evident variations in the Kaapvaal mantle lithosphere. The Matsoku kimberlite has not been extensively mined, and the mantle xenoliths occur naturally as rocks partly buried in the kimberlitic soil. Coarse peridotites are typically garnet lherzolites, and there is a small group of xenoliths rich in clinopyroxene and garnet (Cox et al. 1973; Harte et al., 1987). Unlike the smooth South African nodules (Figure 1), the xenoliths are frequently angular and may reach sizes of around $0.7 \mathrm{~m}$. Many of the larger xenoliths show intrusive sheets or veins, most commonly rich in clinopyroxene, or ilmenite, or phlogopite, but sometimes orthopyroxene and garnet. Amphibole is lacking and they are referred to as the IRPS metasomatic association (Harte et al. 1987). Many peridotites show some evidence of deformation, but such xenoliths show more recystallisation and grain growth than the Kimberley deformed peridotites; and are referred to as 'deformed and recovered peridotites' (Figure 3).

\section{References}

Cox KG, Gurney JJ Harte B (1973) Xenoliths from the Matsoku Pipe. In: Nixon PH (ed) Lesotho Kimberlites, Lesotho national Development Corp., Maseru, pp 76-99

Dawson JB (1987) The MARID suite of xenoliths in kimberlite: relationship to veined and metasomatised peridotite xenoliths. In: Nixon PH (ed) Mantle Xenoliths, John Wiley \& Sons Ltd., Chichester, pp 465-473

Erlank AJ et al. (1987) Evidence for mantle metasomatism in peridotite nodules from Kimberley pipes, South Africa, In: Menzies MA \& Hawkesworth CJ (eds) Mantle metsomatism, Academic Press, London, pp 221-311

Harte B, Winterburn PA, Gurney JJ (1987) Metasomatic and enrichment phenomena in garnet peridotite facies mantle xenoliths from the Matsoku kimberlite pipe, Lesotho. In: Menzies MA \& Hawkesworth CJ (eds) Mantle metsomatism, Academic Press, London, pp 145-220

Hatton CJ Gurney JJ (1987) Roberts Victor eclogites and their relation to the mantle. In: Nixon PH (ed) Mantle Xenoliths, John Wiley \& Sons Ltd., Chichester, pp 465-473

Johnston JL (1973) Petrology and geochemistry of ultramafic xenoliths from the Jagersfontein Mine, OFS, South Africa. In: Extended Abstracts of the Int. Conf. on Kimberlites, University of Cape Town, pp 181-183

Winterburn PA, Harte B, Gurney, JJ (1984) Peridotite xenoliths from the Jagersfontein kimberlite pipe. I Primary and primary-metasomatic mineralogy. Geochim Cosmchim Acta 54:329-341 